\title{
KORELASI INDEKS MASA TUBUH DENGAN KADAR TRIGLISERIDA
}

\author{
Marisa Ester Nurdamayanti ${ }^{1}$, Yunus Elon ${ }^{2}$ \\ ${ }^{1,2}$ Fakultas Keperawatan, Universitas Advent Indonesia \\ E-mail:mrsestr@yahoo.com
}

\begin{abstract}
One cause of risk factors for ischemic stroke is high triglycerides in the blood due to excessive fat intake. This study aims to determine the picture and the relationship between BMI (Body Mass Index) and blood triglyceride (TG) levels in adult women. The research method used was analytic survey with Cross Sectional approach. The sample used is adult women aged 26-45 years who live in Cihanjuang Rahayu Village by using purposive sampling technique. BMI is measured by comparing the results of height calculation with body weight. Triglycerides are taken after fasting for 10 hours and analyzed in a laboratory by Lab personnel. Univariate analysis result showed the majority of respondents had an excess BMI of 73.3\%, normal triglyceride levels of 93.9\%. The results of the correlation test analysis using Pearson Product-Moment Correlation 0.119 with $p$-value $=>0.05$. This show that there is no significant relationship between BMI and triglyceride levels. In the future studies it is necessary to compare between male and female sexes and different age groups in order to provide a complete picture if BMI with triglycerides.
\end{abstract}

Keywords: BMI, Body Mass Index, Triglyceride, Obesity

\begin{abstract}
Abstrak
Salah satu penyebab faktor resiko terjadinya stroke iskemia yaitu tingginya trigliserida dalam darah akibat intake lemak yang berlebihan. Penelitian ini bertujuan untuk mengetahui gambaran dan hubungan antara indeks massa tubuh dan kadar trigliserida (TG) darah pada wanita dewasa. Metode penelitian yang digunakan adalah survei analitik dengan pendekatan Cross Sectional. Sampel yang digunakan yaitu wanita dewasa yang berusia 26-45 tahun yang tinggal di Desa Cihanjuang Rahayu dengan menggunakan teknik purposive sampling. Indeks massa tubuh diukur dengan membandingkan hasil perhitungan tinggi badan dengan berat badan. Trigliserida diambil setelah puasa selama 10 jam dan dianilisa dilaboratorium oleh petugas Lab. Hasil analisis univariate menunjukkan mayoritas responden memiliki indeks massa tubuh berlebih sebanyak 73,3\%, kadar trigliserida normal sebanyak 93,9\%. Hasil analisis Uji korelasi menggunakan Pearson Product-Moment Correlation 0.119 dengan $p$-value $=>0.05$. Hal ini menunjukkan tidak ada hubungan yang bermakna antara indeks massa tubuh dengan kadar trigliserida dalam darah. Pada penelitian selanjutnya perlu membandingkan antara jenis kelamin pria dan wanita serta kelompok usia berbeda agar dapat memberikan gambaran utuh tentang indeks massa tubuh dengan Trigliserida.
\end{abstract}

Kata Kunci: BMI, Trigliserida, Obesitas

\section{Pendahuluan}

Peningkatan trigliserida dalam darah merupakan salah satu penyebab resiko tinggi stroke iskemik. Menurut Agnes, (2014) Trigliserida merupakan lemak darah yang cenderung naik seiring dengan peningkatan konsumsi alkohol, peningkatan berat badan serta diet tinggi gula atau lemak. Peningkatan trigliserida (hipertrigliseridemia) merupakan faktor 
risiko terjadinya penyakit jantung koroner dan stroke. Kadar trigliserida tinggi juga cenderung menyebabkan gangguan tekanan darah dan risiko diabetes mellitus. Lebih jauh (Rahmadani, 2014; Ganda, 2009), menyatakan bahwa Trigliserida merupakan asam lemak yang paling banyak di dalam darah. Tingginya kadar trigliserida sering disertai dengan keadaan kadar HDL rendah. Jika kadar trigliserida meningkat diatas $500 \mathrm{mg} / \mathrm{dl}$ dapat menyebabkan peradangan pada pankreas. Dimana pada wanita peningkatan kadar trigliserida lebih tinggi dibanding pria.

indeks massa tubuh merupakan salah satu alat ukur yang biasa digunakan untuk megklasifikasikan apakah seseorang itu memiliki berat badan kurang, normal, lebih atau obesitas, (WHO, 2016). BMI seseorang diukur dengan membandingkan berat badan (BB) dan tinggi badan (TB). Sesorang yang memiliki BMI >25 masuk dalam kategori gemuk dan jika > 30 masuk dalam kategori obesitas. Obesitas adalah kondisi ketidakseimbangan antara tinggi badan dan berat badan akibat jumlah jaringan lemak tubuh yang berlebihan, umumnya ditimbun dalam jaringan subkutan, pada sekitar organ tubuh dan kadang terjadi infiltrasi ke dalam organ tubuh. (Listiyana, Mardiana, \& Prameswari, 2013) Obesitas menjadi masalah di seluruh dunia baik di negara maju maupun negara berkembang. Sampai sekarang obesitas telah menyebar hingga hampir 3 kali lipat sejak 1975. World Health Organization (WHO, 2016) melaporkan bahwa pada tahun 2016 lebih dari 1,9 miliar manusia berumur $\geq 18$ tahun adalah penderita overweight, dan dari jumlah tersebut lebih dari 650 juta diantaranya adalah penderita Obesitas.

Prevalensi terjadinya obesitas adalah $13 \%$ dari seluruh jumlah manusia di dunia. Dari jumlah tersebut, $11 \%$ diantaranya penderitanya adalah lakilaki, dan $15 \%$ lainnya adalah wanita. Dan di Indonesia sendiri menurut Riset Kesehatan Dasar (Riskesdas 2018) didapati bahwa yang memiliki berat badan lebih atau overweight ada 13,6\% sedangkan yang menderita obesitas ada sekitar $21,8 \%$ dari seluruh penduduk yang berusia $\geq 18$ tahun. Hasil penelitian yang dilakukan oleh Malinti dan Elon (2019) menunjukkan bahwa obesitas pada wanita lebih tinggi dibandingkan dengan pria. Namun pada pria mengalami tren peningkatan dimana usia bergeser dari usia diatas 30 tahun ke usia dibawah 30 tahun.

Sebagian besar lemak yang terdapat di dalam makanan $( \pm 90 \%)$ terdapat dalam bentuk trigliserida, yang akan dihidrolisis menjadi digliserida, monogliserida dan asam lemak bebas. Asam lemak bebas ini akan mengalami esterifikasi dengan triosefosfat untuk membentuk trigliserida, sehingga dapat disimpulkan bahwa peningkatan asupan lemak akan menyebabkan peningkatan kadar trigliserida dalam darah yang disebut dengan hipertrigliseridemia. (Djojosoebagio dan Piliang, 2006)

Berdasarkan masalah dan teori tersebut, maka perlu dilakukan penelitian mengenai hubungan antara Indeks Massa Tubuh dan Kadar Trigliserida Dalam Tubuh pada Wanita Dewasa di Desa Cihanjuang Rahayu

\section{Bahan Dan Metode}

Jenis Penelitian ini adalah survei analitik dengan pendekatan Cross sectional dimana kedua variable dihubungkan dan dianalisa. Populasi penelitian adalah penduduk yang tinggal di salah satu Desa Kab. Bandung Barat. Penelitian ini menggunakan teknik purposive sampling. Sampel penelitian diambil berdasarkan kriteria inklusi yang meliputi penduduk tetap yang tinggal di Desa terkait berjenis kelamin wanita, berusia 26-45 tahun, berbadan sehat, yang bersedia diambil darahnya, dan bersedia menjadi responden dengan menandatangani informed consent. Responden dewasa dengan gangguan metal, atau menderita penyakit kronis, yang menyebabkan ketidak mampuan secara fisik, atau dalam keadaan sakit yang membutuhkan perawatan tidak akan diikutsertakan dalam penelitian ini.

Dari total populasi wanita dewasa yang memenuhi kriteria inklusi diambil sampel dengan menggunakan rumus slovin, didapatkan jumlah sampel sebanyak 45 responden. Penelitian ini dilakukan pada bulan September 2019.

Sebelum proses pengambilan data penelitian ini, telah mendapatkan sertifikat layak etik dari institusi terkait. Proses pengambilan sampel dilakukan dengan mendatangi calon respoden ke rumah masing-masing, jika responden memenuhi kriteria, peneliti akan menjelaskan tujuan penelitian dan jika bersedia maka peneliti memberikan informed consent kepada responden. Peneliti memberikan kesempatan bagi responden untuk bertanya sebelum menandatangani informed consent. Responden yang yang bersedia diminta untuk berpuasa selama 10 jam dimulai dari pukul 22 malam sampai pukul 8 pagi. Sebelum pengambilan darah oleh petugas laboratorium, peneliti mengukur tinggi badan dengan menggunakan stature meter dan selanjutnya mengukur berat badan dengan timbangan digital yang terkalibrasi, data tersebut dihunakan untuk menghitung BMI. Hasil perhitungan BMI diklasifikasikan berdasarkan kategori BMI. 
Tabel 1. Kategori Indeks Massa Tubuh

\begin{tabular}{cc}
\hline Kategori & Rentang \\
\hline Underweight & $<18,5$ \\
Normal & $18,5-24,9$ \\
Overweight & $25-29,9$ \\
Obesitas & $\geq 30$ \\
\hline
\end{tabular}

World Health Organization, 2016

Selanjutnya petugas akan mengambil darah dengan menggunakan vacuum spuit $\div 3 \mathrm{cc}$ yang akan dianalisis menggunakan mesin cobas integra yang telah dikalibrasi. Kemudian hassil akan dinterperatasikan dengan menggunakan standard pada tabel.

\section{Tabel 2. Kategori Kadar Trigliserida}

\begin{tabular}{ll}
\hline Klasifikasi & Kadar Trigliserida $(\mathrm{mg} / \mathrm{dL}$ \\
\hline Normal & $<150 \mathrm{mg} / \mathrm{dL}$ \\
Batas Tinggi & $150-199 \mathrm{mg} / \mathrm{dL}$ \\
Tinggi & $200-499 \mathrm{mg} / \mathrm{dL}$ \\
Sangat Tinggi & $>500 \mathrm{mg} / \mathrm{dL}$ \\
\hline
\end{tabular}

Sumber: www.alodokter.com

Analisis data dilakukan dengan menggunakan analisis dekskriptif dan analisis korelasi. Analisis deskriptif digunakan untuk mengetahui informasi gambaran usia, status pernikahan, tingkat pendidikan, BMI, dan kadar trigliserida. Hasil analisis menunjukkan bahwa data berdistribusi normal sehingga analisis korelasi menggunakan uji Pearson product moment yang digunakan untuk mengetahui hubungan antara BMI dengan kadar trigliserida.

\section{Hasil dan Pembahasan}

Karakteristik responden berdasarkan usia, indeks masa tubuh dan kadar trigliserida disajikan dalam bentuk tabel berikut ini;

Tabel 3. Karakteristik Responden Berdasarkan Usia

\begin{tabular}{lcc}
\hline \multicolumn{1}{c}{ Usia } & Frekuensi & Persentase \\
\hline $\begin{array}{l}\text { Dewasa Muda } \\
\text { (26-35 tahun) }\end{array}$ & 21 & $46,7 \%$ \\
$\begin{array}{l}\text { Dewasa Tua } \\
\text { (36-45 tahun) }\end{array}$ & 24 & $53.3 \%$ \\
\hline Sum & & \\
\hline
\end{tabular}

Sumber: data primer
Gambaran tersebut memperlihatkan mayoritas penduduk wanita di Desa Cihanjuang Rahayu yang bersedia menjadi responden penelitian adalah yang masuk golongan Dewasa Tua dengan persentase $53,3 \%$ sebanyak 24 orang. Sedangkan 21 orang lainnya masuk dalam golongan dewasa muda dengan persentase $46,7 \%$. Usia dapat berpengaruh pada kadar trigliserida karena seperti yang ditulis dalam Heriyanti (2012) yang menemukan adanya hubungan yang erat antara usia dengan kadar trigliserida.

\section{Karakteristik Indeks Massa Tubuh dan Kadar Trigliserida Responden}

Tabel 4. Karakteristik Responden Berdasarkan BMI

\begin{tabular}{ccc}
\hline Klasifikasi & Frekuensi & Persentase \\
\hline Normal & 12 & $26,7 \%$ \\
Gemuk & 19 & $42,2 \%$ \\
Obesitas & 14 & $31,1 \%$ \\
\hline
\end{tabular}

Sumber: Data Primer

Berdasarkan tabel 4 diatas dapat disimpulkan bahwa mayoritas penduduk wanita di Desa Cihanjuang Rahayu yang bersedia menjadi responden penelitian adalah masuk golongan Gemuk berdasarkan penghitungan BMI dengan persentase sebanyak $42,2 \%$ sebanyak 19 orang. 14 orang lainnya masuk dalam golongan obesitas dengan persentase $31,1 \%$. Sedangkan yang masuk dalam golongan normal ada 12 orang dengan prsentase $26,7 \%$.

Tabel 5. Karakteristik Responden Berdasarkan Kadar Trigliserida

\begin{tabular}{lll}
\hline Klasifikasi & Frekuensi & Persentase \\
\hline Normal & 42 & $93,9 \%$ \\
Batas Tinggi & 3 & $6,7 \%$ \\
\hline
\end{tabular}

Sumber: Data primer

Berdasarkan tabel diatas dapat disimpulkan bahwa mayoritas penduduk wanita di Desa Cihanjuang Rahayu yang bersedia menjadi responden penelitian adalah memiliki Kadar Trigliserida dalam batas normal kurang dari $150 \mathrm{mg} / \mathrm{dL}$ dengan persentase 93,9\%. 3 responden sisanya masuk ke dalam golongan batas tinggi sebesar $6,7 \%$.
Data pada tabel 3 memperlihatkan gambaran karakteristik responden berdasarkan usia. 


\title{
Uji Analisis Hubungan Indeks Massa Tubuh dengan Kadar Trigliserida
}

\author{
Tabel 6. Analisa Uji Pearson Product Moment Hubungan Indeks Massa Tubuh dengan kadar \\ Trigliserida
}

\begin{tabular}{ccccc}
\hline Variabel & Mean & Std. Deviasi & $\begin{array}{c}\text { Koefisien } \\
\text { Korelasi }\end{array}$ & $\begin{array}{c}\text { Sig. } \\
(2-\text { tail })\end{array}$ \\
\hline BMI & 28.4547 & 4.57632 & & \\
Trigliserida & 94.1556 & 35.58725 & 0.119 & 0.438 \\
\hline
\end{tabular}

Dari tabel diatas didapati bahwa berdasarkan Nilai Signifikansi Sig. (2-tailed) bernilai 0.438 yaitu lebih dari 0.05 yang berarti tidak ada korelasi hubungan bermakna antara indeks massa tubuh dengan Kadar Trigliserida. Sedangkan dari nilai $\mathrm{r}$ menurut rumus Pearson's Correlation bernilai 0.119 yaitu kuang dari $r$ tabel 0.287 berarti hubungan korelasi antara keduanya tidak ada. Atau korelasi sangat lemah jika ditilik dari penggolongan kekuatan hubungan korelasi menurut Jonathan Sarwono (2006).

Hasil penelitian ini mendukung penelitian sebelumnya yang telah dilakukan oleh Koampa, Karel dan Marthen (2016) yang menunjukan bahwa tidak ada hubungan yang signifikan antara BMI dengan Kadar Trigliserida.

Sejalan juga dengan penelitian dari Hartini dan Wiranti pada tahun 2017 yang juga menunjukan bahwa tidak ada hubungan yang signifikan antara BMI dengan Kadar Trigliserida. Hal tersebut kemungkinan dapat terjadi karena asupan energi responden sesuai dengan jumlah yang dibutuhkan oleh tubuh sehingga tidak terjadi penimbunan energi dalam bentuk lemak sebagai cadangan energi yang akan berpengaruh pada berat badan responden. Bisa juga karena ada faktor-faktor lain seperti asupan lemak, pola makan, dan faktor usia (Hidayati, Yulianti, dan Kartika, 2017).

Menurut pernyataan Putri dan Dian (2015) menyebutkan bahwa kadar trigliserida darah dapat dipengaruhi oleh: Diet tinggi kerbohidrat, asupan protein, asupan lemak, diet tinggi serat, faktor genetik, usia, stres, penyakit hati, dan hormonhormon dalam darah.

Sehubungan dengan usia, responden yang digunakan dalam jurnal ini adalah wanita usia dewasa muda dan dewasa tua, sehingga pengaruh metabolisme tubuh dalam pemecahan trigliseridanya masih berjalan sesuai fungsinya, berbeda dengan lansia yang sudah berusia 50-70 seperti dijelaskan pada jurnal milik Heriyanti (2012) dimana semakin bertambahnya usia, kadar trigliserida semakin juga ikut meningkat.

Berdasarkan data dari International Diabetes Federation (2005), angka kejadian sindrom metabolik lebih banyak terjadi pada usia 80-89 tahun yaitu sebesar $64 \%$ pada wanita, sedangkan untuk usia 20-29 tahun sebesar 9\%. Dan jika dilihat pada responden penelitian ini rentang usianya 26-45 yang angka kejadiannya hanya mencapai sebesar $22 \%$. Jadi dapat ditarik kesimpulan bahwa olah metabolisme tubuh dari responden yang diambil masih normal, sehingga masih bisa mengolah metabolisme tubuh dengan baik, sehingga tidak terdapat peningkatan kadar trigliserida.

Output dari hasil trigliserida yang diambil dari sample yang dikumpulkan bisa juga dipengaruhi oleh asupan lemak dan karbohidrat yang dikonsumsi seperti yang dijelaskan oleh Hidayati, dkk tahun 2006 di Yogyakarta dalam penelitiannya ia mendapati bahwa asupan lemak dan karbohidrat berhubungan dengan kadar trigliserida. Didukung dengan pernyataan dari Murray, dkk (1997) dalam bukunya yang menyatakan bahwa pembentukan 
piruvat dan asetil-KoA akan meningkat apabila terjadi peningkatan konsumsi karbohidrat. Dan jika terjadi peningkatan asetil-KoA maka asam lemak dalam tubuh juga ikut meningkat, dimana asam lemak tersebut akan menjadi trigliserida setelah pemrosesan melaluie sterifikasi dengan tri fosfat yang dihasilkan dari glikoslisis. Hal ini sejalan dengan hasil quesioner yang diisi oleh responden pada saat dilakukan pendataan yang menyatakan mayoritas dari responden hanya mengkonsumsi sekitar \pm 2 porsi karbohidrat dalam sehari (600 kalori) dan jarang makan makanan seperti daging kambing, daging sapi, mentega, keju.

Pola makan yang mereka lakukan dirumah juga tidak diatur. Seperti jarang makan karbohidrat pada pagi hari dan hanya makan cemilan saat siang hari, dan akan kembali mengkonsumsi karbohidrat pada malam hari saat mereka merasa lapar. Sehingga dapat diambil kesimpulan bahwa dari jenis makanan yang dikonsumsi oleh responden, dapat berkaitan dengan nilai kadar trigliserida dalam darah.

Jenis makanan yang lebih sering dikonsumsi oleh mayoritas responden adalah makanan berserat tinggi. Seperti jenis sayuran brokoli, kentang, seledri, buncis, wortel, kangkung, bayam dan buahbuahan seperti apel, pisang, mangga, alpukat, pir. Dan juga kacang-kacangan seperti kacang merah, kacang tanah, dan kedelai. Menurut Yap HC, dkk. (2007) dalam Ramadhani dan Enny tahun 2014 menyatakan dalam jurnalnya bahwa serat larut air berfungsi dalam memperlambat waktu pengosongan lambung, meningkatkan ketebalan lapisan intestinal yang berfungsi sebagai tempat absorpsi lipid. Dan juga dapat menghambat absorpsi dan metabolisme trigliserida dengan cara mengikat asam empedu dan membentuk misel yang akan dikeluarkan melalui feses. Sehingga dapat berdampak pada metabolisme trigliserida dalam tubuh.

Hal yang lain yang dapat mempengaruhi hasil dari penelitian ini juga dimungkinkan karena factor genetic dan aktifitas fisik dari responden. Karena hampir semua dari responden penelitian yang mengikuti penelitian ini adalah pekerja aktif di lingkungan rumahnya. Seperti tukang kebun, dan pengumpul sayuran. Selain itu, dalam kuesioner yang dibagikan, mayoritas dari responden menyatakan tidak memiliki penyakit keturunan seperti Diabetes Melitus, Hipertensi, Jantung, maupun penyakit lainnya. Seperti dalam jurnal milik Krishna dan Gopinah (2011), yang menyatakan bahwa ada hubungan yang signifikan antara aktifitas fisik dengan kadar trigliserida. Yang menyatakan bahwa semakin meningkatnya aktifitas fisik maka akan berakibat menurunnya kadar trigliserida dalam tubuh. Dimana terjadi pembakaran sel lemak dan pembentukan energi dalam tubuh pada saat dilakukan aktivitas fisik.

Berbeda dengan penelitian milik Hidayati, dkk (2006) yang menyatakan adanya hubungan yang signifikan antara BMI dengan peningkatan Trigliserida. Dalam jurnal ini dinyatakan bahwa IMT mempunyai interaksi dengan asupan lemak dalam mempengaruhi kadar trigliserida dan memberikan kontribusi terhadap perubahan kadar trigliserida sebesar $17 \%$. Juga dalam hubungannya dalam asupamn karbohidrat, karena semakin banyak karbohidrat yang masuk ke dalam tubuh, kadar trigliserida di dalam darah pun ikut naik. Ditunjang oleh karena makanan pokok di Indonesia merupakan karbohidrat yaitu nasi. Dan jurnal milik Idapola (2009) yang menyatakan responden dengan IMT berlebih memiliki resiko $3 \mathrm{x}$ lebih tinggi untuk mengalami hipertrigliseridemia.

\section{Kesimpulan dan Saran}

\section{Kesimpulan}

Mayoritas responden memiliki indeks massa tubuh berlebih sebanyak 73,3\%, dan memiliki kadar trigliserida normal sebanyak 93,9\%. Menurut perhitungan menggunakan Pearson's tidak ditemukan adanya hubugan yang signifikan antara BMI dengan kadar triliserida dalam darah pada wanita dewasa berusia 26-45 tahun.

\section{Saran}

Dengan keterbatasannya penelitian ini dianjurkan pada peneliti selanjutnya untuk melakukan penelitian yang serupa dengan mengambil sample lebih banyak dengan indeks massa tubuh yang lebih bervariasi. Dan untuk adanya penelitian selanjutnya yang membandingkan antara jenis kelamin pria dan wanita serta kelompok usia berbeda agar dapat memberikan gambaran utuh tentang indeks massa tubuh dengan Trigliserida.

\section{Daftar Pustaka}

Agnes, S.H. (2014). Biokomia Kesehatan Yogyakarta. Nuha Medika.

Djojosoebagjo, S., Piliang W.G. (1998). Nutrisi Lemak. Fisiologi Nutrisi Edisi 2. Jakarta. Universitas Indonesia.

Gandha, M. (2009). Hubungan Perilaku Dengan Prevalensi Dislipidemia Pada Masyarakat Kota Ternate Tahun 2008. Jakarta: Fakultas Kedokteran UI. 
Hartini, H., Wiranti, F. (2017). Hubungan Indeks Massa Tubuh (IMT) Terhadap Kadar Trigliserida Pada Wanita Usia 40-60 Tahun. Akademi Kesehatan John Paul II Pekanbaru. Pekanbaru.

Heriyanti. (2012). Hubungan Usia dengan Kadar Trigliserida dalam Darah pada Lansia 50-70 Tahun yang Memeriksakan Diri di Balai Laboratorium Kesehatan Propinsi Sumatera Utara. Skripsi. Fakultas Biologi. Universitas Medan Area, Medan.

Hidayati, S.N., Haman, H, Lestariana, W.. (2006). Hubungan Asupan Zat Gizi dan Indeks Massa Tunbuh dengan Hiperlipidemia pada Murid SLYTP yang Obesitas di Yogyakarta. Fakultas Kedokteran. Universitas Gajah Mada.

Hidayati, R.D., Yulianti, Y., Kartika, R.P. (2017). Hubungan Asupan Lemak Dengan Kadar Trigliserida Dan Indeks Massa Tubuh Sivitas Akademika UNY. Fakultas Biologi. Universitas Negeri Yogyakarta.

Idapola, S.S.J. (2009). Hubungan Indeks Massa Tubuh dengan Keadaan Biokimia Darah pada Karyawan PT. Asuransi Jiwa Bumi Asih Jaya, Jakarta. Analisis Data Sekunder 2008. Universitas Indoneisia.

Internasional Diabetes Federation. (2005). Metabolic Syndrome. Available at: http://www.idf.org/

Kementrian Kesehatan Republik Indonesia. (2018). Riset Dasar Kesehatan Dasar Tahun 2018. Jakarta: Badan Penelitian dan Pengembangan Kesehatan Kementrian RI: 2018

Koampa, P.H, Karel, P., Marthen, C.P.W. (2016). Hubungan Indeks Massa Tubuh Dengan Profil Lipid Pada Pasien Diabetes Melitus Tipe 2. Fakultas Kedokteran. Universitas Sam Ratulangi Manado.
Krishna, M.M., Gopinath, V. (2011). Effect of aerobic excercise on lipoprofile of middle aged man. World Journal of Science and Technology.

Listyana, A.D., Mardiana, M., Prameswari, G.N. (2013). Obesitas Sentral dan Kadar Kolesterol Darah Total. Jurnal Kesehatan Masyarakat

Malinti, E.. Elon, Y. (2019) Hubungan Asupan Natrium, Kalium: Indeks Masa Tubuh, Lingkar Pinggang dengan Tekanan Darah Pria Dewasa Muda. Riset Informasi Kesehatan 8(1), 1-8.

Murray, R.K., Granner, D.K., Mayes, P.A., Rodwell, V.W. (1997). Harper's Biochemistry Edisi ke24, Hartono, A, (alih bahasa), Jakarta EGC

Nugraha, A. (2014). Hubungan Indeks Massa Tubuh Dengan Kadar Kolesterol Total Pada Guru Dan Karyawan SMA Muhammadiyah 1 Dan 2 Surakarta. Skripsi. Fakultas Kedokteran. Universitas Muhammadiyah, Surakarta

Putri, R.S., Dian, I.A. (2015). Obesitas Sebagai Faktor Resiko Peningkatan Kadar Trigliserida. Fakultas Kedokteran. Universitas Lampung

Ramadhani, A, Enny P. (2014). Perbedaan Kadar Trigliserida Sebelum dan Setelah Pemberian Sari Bengkuang (Pachyrrhizus erosus) Pada Wanita. Skripsi. Fakultas Kedokteran. Universitas Diponegoro, Semarang.

Sarwono, J. (2006). Korelasi. Available at: https://www.jonathansarwono.info/korelasi/korel asi.htm

WHO. (2016). BMI Classification. Availabble at: https://www.who.int/

WHO. (2018). Obesity and Overweight. Available at: https://www.who.int/news-room/factsheets/detail/obesity-and-overweight 